\title{
OPTIMIZATION OF BOVINE LEATHER SOAKING PROCESS
}

\author{
Ângela QUEIRÓS, Vânia F.M. SILVA*, Telma SANTOS, António CRISPIM \\ CIETI/ISEP - Centre of Innovation on Engineering and Industrial Technology/IPP School of Engineering, Rua Dr. António \\ Bernardino de Almeida, 831, 4200-072 Porto, Portugal
}

\section{OPTIMIZATION OF BOVINE LEATHER SOAKING PROCESS}

ABSTRACT. High quantities of water, chemical reagents and time are needed in leather processes which result in a huge investment for the tanning industry, therefore it is necessary to optimize it. Soaking is the first stage of leather process, responsible for cleaning and re-hydrating the skin through an aqueous bath. In this work, to study an ecological approach of the soaking step, two different types of soaking were evaluated comparing the traditional method against an enzymatic method. Bactericide, a wetting agent, a degreaser and enzymes were applied on the skins with two ways of preservation, salted skin and green skin. The $\mathrm{pH}$ value, conductivity and hide weight were determined to evaluate the process. The enzymatic method showed a better soaking performance giving good indications for an ecological approach of the soaking process.

KEY WORDS: green skin, leather process, salted skin, soaking

\section{OPTIMIZAREA PROCESULUI DE ÎNMUIERE A PIELII BOVINE}

REZUMAT. În procesul de fabricare a pielii sunt necesare cantități mari de apă, reactivi chimici și timp, care au ca rezultat o investiție mare pentru industria de pielărie, prin urmare este necesară optimizarea acestui proces. Înmuierea este prima etapă a prelucrării pielii, fiind responsabilă pentru curățarea și re-hidratarea pielii într-o baie de apă. În această lucrare, pentru a studia o abordare ecologică a operației de înmuiere, s-au evaluat două tipuri diferite de înmuiere, comparând metoda tradițională cu o metodă enzimatică. S-au aplicat bactericid, un agent de umectare, un degresant și enzime pe pieile conservate în două moduri, prin sărare și ecologic. S-au determinat valoarea pH-ului, conductivitatea și greutatea pielii pentru a evalua procesul. Metoda enzimatică a demonstrat o performanță mai bună la înmuiere, oferind indicaţii bune pentru o abordare ecologică a procesului de înmuiere.

CUVINTE CHEIE: piele crudă, prelucrarea pielii, piele sărată, înmuiere

\section{L'OPTIMISATION DU PROCÉDÉ DE TREMPAGE DE LA PEAU BOVINE}

RÉSUMÉ. De grandes quantités d'eau, de réactifs chimiques et de temps sont nécessaires dans le processus de fabrication de la peau, ce qui entraîne un investissement important dans l'industrie du cuir, raison pour laquelle il est nécessaire d'optimiser ce processus. Le trempage est la première étape du traitement de la peau, étant responsable du nettoyage et de la réhydratation de la peau dans un bain d'eau. Dans cet article, pour étudier une approche écologique de l'opération de trempage, deux types différents de trempage ont été évalués, en comparant la méthode traditionnelle avec une méthode enzymatique. Bactéricide, agents mouillants, dégraissants et enzymes ont été appliqués sur des peaux préservées de deux manières, salées et écologiques. La valeur $\mathrm{du} \mathrm{pH}$, la conductivité et le poids de la peau ont été déterminés pour évaluer le processus. La méthode enzymatique a démontré une meilleure performance de trempage, fournissant de bonnes indications pour une approche écologique du processus de trempage.

MOTS CLÉS : peau verte, traitement de la peau, peau salée, trempage

* Correspondence to: Vânia F.M. SILVA, CIETI/ISEP - Centre of Innovation on Engineering and Industrial Technology/IPP School of Engineering, Rua Dr. António Bernardino de Almeida, 831, 4200-072 Porto, Portugal E-mail: vfmsi@isep.ipp.pt, Tel +351 228340500 


\section{INTRODUCTION}

Leather industry is an important activity in many developing countries, which is dependent on the agro economy [1] and is responsible for the transformation of animal skin, a putrescible biological material in a stable and imputrescible product, the leather [2]. An important role in the tanning industry is the research focused on the improvement of the quality of leather ensuring a reduction of time, water and energy consumption, as well as of the pollution generated [3].

There are four major groups of subprocesses required to achieve finished leather: beamhouse operation, tanning, retanning and finishing processes [2].

Soaking is the first step of the beamhouse, which is a set of operations which constitute the first part of the tanning process. Soaking can be divided in two stages. The first soaking is used to make a first cleaning of the skin by removing a great amount of dirt and unwanted materials attached to it. Another objective of the first soaking is to increase the skin water content in order to reach more effectiveness in the subsequent cleaning [3]. In the second soaking, raw skins are treated with water and small quantities of imbibing substances, in order to hydrate the skin proteins and open the contracted fibers of the dried skins, solubilize the denatured proteins, eliminate the salt, used in the preservation step, and the residuals of blood, excrement and earth, attached to the skin [2].

Common soaking agents are alkali, sodium sulphide, salt and some surfactants. However, these materials often lead to environmental pollution.

In order to improve the technology, to facilitate skin soaking process, enzymes have been used as one of the most promising substitutes for traditional chemicals [4]. Protease and lipase enzymes seems to be quite promising as they can be efficiently used in the beamhouse operations of tanneries for leather manufacturing processes [5]. Some alkaline proteases are used to ensure faster absorption of water and to reduce the time required for skin soaking. A multienzyme system is often used in skin enzymatic treatment, because the multi-enzyme system would be more efficient through synergy effect of different enzymes [4]. However, many factors affect the enzymes in soaking process, such as enzymes ratios, enzymes loadings, presence of surfactants [6], enzymes species and some other additives [4]. In general, enzymatic activity in an aqueous medium, is strongly dependent on the $\mathrm{pH}$ values and salt factors such as concentration and species [7].

Other factor which can adversely influence the course of soaking and, consequently, the quality of leather, is the number and strains of microorganisms present in the aqueous medium, especially if they include proteolytic bacteria [8]. Another limited value is the dryness of the hide.

Soaking time and degree of diffusion of chemicals through the hide, achieved by drumming/paddle action are two more factors that influence the process [9].

In many cases, the soaking is performed in a drum because of the mechanical effect provided, assistance in accelerating the penetration of water and chemicals added in the float into the skin. However, there are some cases where the mechanical effect is not advisable, because it could damage the dried skin during the first soaking, causing excessive fiber breakage and even defects in the grain. To avoid this, the use of pits or paddles in the first soaking with little or without mechanical effect is an option [3].

In what concerns the process time, the longest the soaking time, 8-20 hours for wet salted hide or 24-48 hours for dried skins, the higher will be the putrefaction rate by bacterial action, which should be avoided with a careful procedure and addition of bactericides [9]. Not only could these effects be prevented by converting biological materials into a stable product, resistant to microbial activities but also the resistance to wet and dry heat is enhanced [10].

In this work, an enzymatic soaking was evaluated against a traditional soaking in order to improve more efficient and ecological soaking.

\section{EXPERIMENTAL}

\section{Materials and Methods}

Tests were performed with bovine skins, which had different steps of preservation, salted skin and green skin. Salted skin was provided by company Curtumes Aveneda and green skin was supplied by company Couro Azul. 
The bactericide Busan 85 and Buzyme enzymes were provided by the company Buckmann and the chemicals Indiwet were delivered by the company Indinor, a chemical company located in Portugal.

The soaking trials were performed in laboratory-scale tannery drums (LFA-9293, Mathis), with temperature and speed control. Other instruments included a Hach Conductivity/ TDS meter, Consort C562, Metrhom 691 pH Meter, Kern ALJ 220 - 4NM were used to analyze the soaking process.

\section{Soaking Tests Methodology}

Two different types of soaking were studied to compare the traditional method against the enzymatic method.

Soaking method was processed at 25 degrees and agitated with a little mechanical effect to avoid damaging the skin.

Samples of hide were first cleaned with $0.25 \% \mathrm{w} / \mathrm{w}$ sodium carbonate and $250 \% \mathrm{w} / \mathrm{w}$ of water for $30 \mathrm{~min}$ followed by a second soaking step with the addition of enzymes, bactericide and other chemicals.

For the second soaking step, $0.1 \% \mathrm{w} / \mathrm{w}$ bactericide Busan 85 and $0.25 \% \mathrm{w} / \mathrm{w}$ sodium carbonate were added in all the trials.

In the soaking named MF1, a traditional wetting agent and a traditional degreaser, respectively Indiwet $\mathrm{OH} 30$ and Indiwet L30 were used, and in the soaking MF2 two enzymes, Buzyme 148 (protease) and Buzyme 7707 (lipase), were used.

Table 1 shows the soaking procedure where the percentages of inputs were calculated based on the hide mass.

Table 1: Soaking procedures

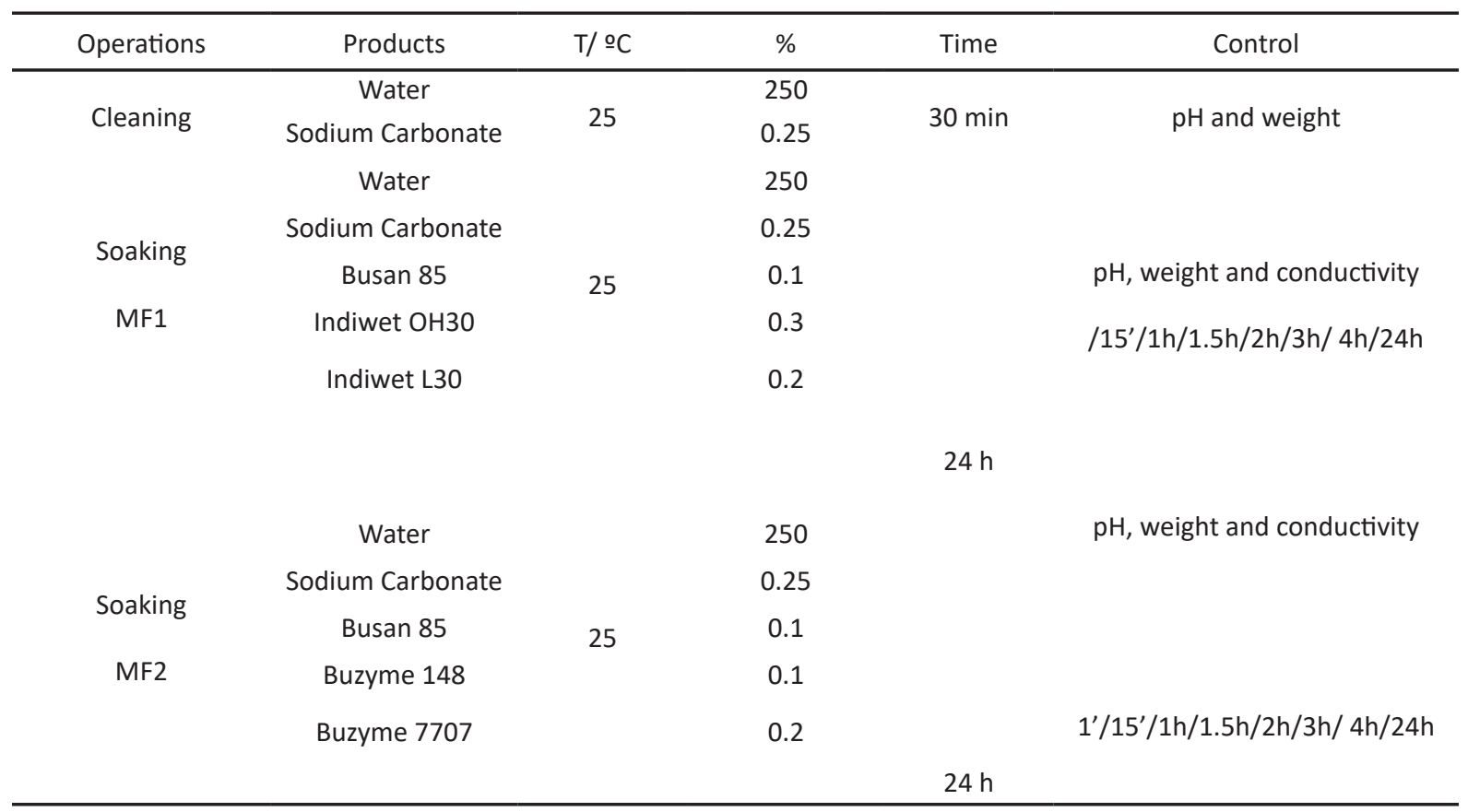

To evaluate the soaking performance, $\mathrm{pH}$ value, conductivity and hide weight gain were measured at different intervals ( 1 and 15 minutes and 1, 1.5, 2, 3, 4 and 24 hours).

After each evaluation, the hide pieces and liquor samples were returned to the drums and the process continued until complete 24 hours.

\section{Analysis}

Different studies were performed to evaluate the soaking process: conductivity, $\mathrm{pH}$ value and hides weight gain.

In the soaking liquor the conductivity measurement was evaluated with Hach Conductivity/TDS meter, Consort C562 and the $\mathrm{pH}$ value controlled with Metrhom $691 \mathrm{pH}$ Meter. 
For the weight gain, the hides were drained by 2 minutes in order to standardize this procedure before the measurement in an analytical balance (Kern ALJ 220 - 4NM).

\section{RESULTS AND DISCUSSION}

In the experimental trials, all parameters were evaluated at zero time, before the addition of the skin to the soaking liquor.

Table 2 shows the $\mathrm{pH}$ values obtained for the different trials. The trial named MF1 refer to trial when a traditional wetting agent and a traditional degreaser were used, in the test named MF2 two enzymes were used, Buzyme 148 (protease) and Buzyme 7707 (lipase). MF1_G and MF2_G were tested with green skin $(G)$. The trials with salted skin (S) were named with MF1_S and MF2_S.

This parameter shows a similar behavior in all the trials with a decreasing of $28 \%$ from initial (zero time) to final value ( 24 hours), except for the trial MF2_S which presents a decreasing of $40.5 \%$. After 1 hour of soaking, there is a $\mathrm{pH}$ stabilization for all the trials between 8 and 9.5, except for the trial MF2_S.

Table 2: $\mathrm{pH}$ values obtained in the soaking tests in each interval of time

\begin{tabular}{ccccc}
\hline $\begin{array}{c}\text { Hide } \\
\text { Test } \\
\text { Samples time }\end{array}$ & MF1_G & MF2_G & MF1_S & MF2_S \\
\hline 0 min & 11.31 & 11.34 & 11.46 & 11.47 \\
1 min & 10.72 & 10.44 & 10.82 & 11.20 \\
15 min & 10.29 & 9.94 & 10.21 & 10.33 \\
1 hour & 9.64 & 9.31 & 9.69 & 9.68 \\
1.5 hours & 9.28 & 9.08 & 9.38 & 9.07 \\
2 hours & 9.18 & 9.07 & 9.25 & 8.78 \\
3 hours & 9.00 & 8.94 & 9.08 & 8.38 \\
4 hours & 8.95 & 8.87 & 9.04 & 8.25 \\
24 hours & 8.06 & 8.26 & 8.24 & 6.83 \\
\hline
\end{tabular}

In what concerns conductivity of soaking liquor, for green skin (Figure 1), the trial MF2_G (soaking with enzyme) reached the highest result followed by the soaking test with wetting agent and a degreaser (MF1_G). It is also observed that both trials become practically stable after 2 hours.

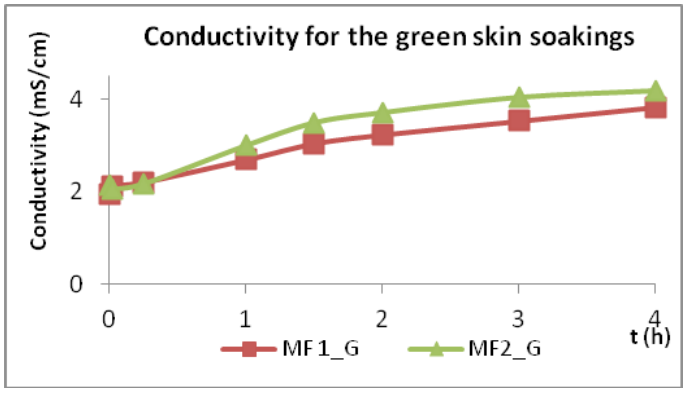

Figure 1. Conductivity values of green skin soakings for trials MF1_G and MF2_G

Figure 2 illustrates the results of conductivity for salted skin soakings. In this case, soaking with wetting agent and degreaser obtained higher results than with enzyme. However, the behavior is very similar for both trials.

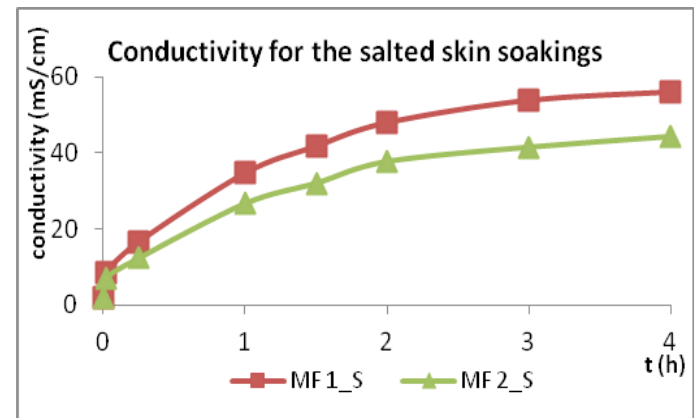

Figure 2. Conductivity values of salted skin soakings for trials MF1_S and MF2_S

For 24 hours trial time there weren't visible changes for the parameter studied (more 5.2\% for MF1_S; more $10.1 \%$ for MF2_S) when compared with results obtained for 4 hours. 
Comparing the conductivity of both liquors (green and salted skin), salted skin presents a higher conductivity than green skin, as was expected.

Figure 3 and Figure 4 represent the effect of soaking in the hide weight gain on green and salted skin respectively. The hide weight gain was analyzed to evaluate the evolution of hide rehydration, after water diffusion into the hide. The weight gain was calculated as the ratio between the weight change (difference between the final weight and the initial weight) and initial weight, in percentage.

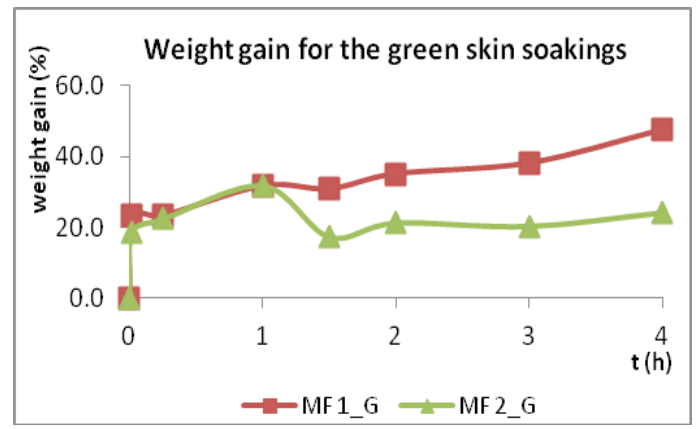

Figure 3. Hide weight gain evaluation for green skin for trials MF1_G and MF2_G

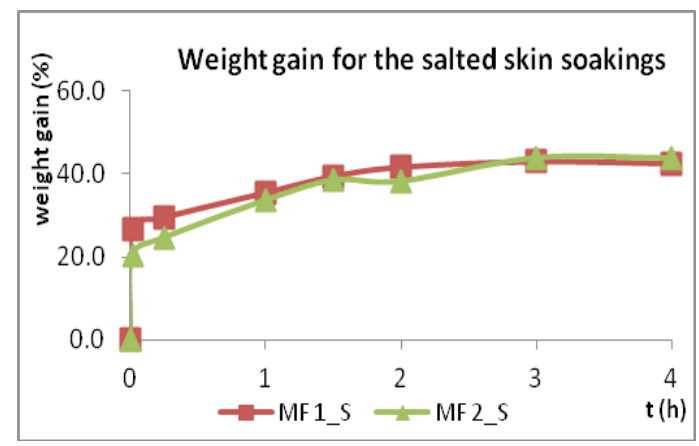

Figure 4. Hide weight gain evaluation for salted skin for trials MF1_S and MF2_S

Figure 3 shows significantly higher values for soaking with wetting agent and degreaser (MF1_G) than with enzyme (MF2_G), namely after 1 hour of soaking. After 1 hour for soaking with enzyme (MF2_G) there was a reduction in the weight gain, not expected.

In Figure 4, for salted skin soaking, the behavior is very similar showing the same performance for the enzyme soaking against the traditional soaking. For MF1, $42.5 \%$ was the gain for salted skin and $47 \%$ for green skin.

Table 3 shows values for tests after 24 hours. Ending 24 hours there weren't major changes for the parameter studied when compared with results for 4 hours.

Table 3: Hide weight gain for 24 hours

\begin{tabular}{ccc}
\hline & \multicolumn{2}{c}{ Weight gain (\%) } \\
Test & $\begin{array}{c}\text { Green } \\
\text { skin }\end{array}$ & Salted skin \\
& 42,6 & \\
\hline MF1 & 25,2 & 41,1 \\
MF2 & & 41,6 \\
\hline
\end{tabular}

Analyzing all the results obtained for 24 hours, MF1, and MF2 present a similar behavior for the salted skin with a result not expected for the green skin.

\section{CONCLUSIONS}

The necessity to optimize the leather process due to the huge investment and negative effects of using high quantities of water, chemical reagents and time, has led to this study.

Concerning the $\mathrm{pH}$, after 1 hour of soaking, there is $\mathrm{pH}$ stabilization for all the trials between 8 and 9.5. The analysis of the conductivity showed that salted skin soaking bath presents a higher conductivity than green skin, as was expected. On the other hand, a similar behavior is observed for the two soaking systems. In what concerns the weight gain, the enzymes soaking achieved approximately the same results than the traditional soaking with a similar behavior.

In conclusion, it can be said that enzyme soaking has the same performance compared to the traditional soaking with the advantage of having a lower environmental impact on the waste water because enzymes are biodegradable compared to the traditional wetting and degreasing chemicals.

\section{Acknowledgments}

The authors acknowledge the Foundation for Science and Technology (FCT) for funding this research by the project FCT UID/ EQU/03470/2013. 


\section{REFERENCES}

1. Rao, J.R., Chandrababu, N.K., Muralidharan, C., Nair, U.B., Rao, P.G., Ramasami, T., J Clean Prod, 2003, 11, 591-599, https://doi. org/10.1016/S0959-6526(02)00095-1.

2. Lofrano, G., Meriç, S., Zengin, G.E., Orhon, D., Sci Total Environ, 2013, 461462, 265-281, https://doi.org/10.1016/j. scitotenv.2013.05.004.

3. Morera, J.M., Bartolí, E., Singla, C., J Clean Prod, 2013, 59, 79-85, https://doi. org/10.1016/j.jclepro.2013.06.060.

4. Ma, J., Hou, X., Gao, D., Lv, B., Zhang, J., J Clean Prod, 2014, 78, 226-232, https:// doi.org/10.1016/j.jclepro.2014.04.058.

5. Saran, S., Mahajan, R.V., Kaushik, R., Isar, J., Saxena, R.K., J Clean Prod, 2013, 54, 315-322, https://doi.org/10.1016/j. jclepro.2013.04.017.

6. Van Dyk, J.S., Pletschke, B.I., Biotechnol Adv, 2012, 30, 1458-1480, https:// doi.org/10.1016/j.biotechadv.2012.03.002.
7. Egusa, S., Kitaoka, T., Igarashi, K., Samejima, M., Goto, M., Wariishi, H., J Mol Catal B Enzym, 2010, 67, 225-230, https:// doi.org/10.1016/j.molcatb.2010.08.010.

8. Orlita, A., Int Biodeterior Biodegradation, 2004, 53, 157-163, https:// doi.org/10.1016/S0964-8305(03)00089-1.

9. Sivakumar, V., Rao, P.G., J Clean Prod, 2001, 9, 25 - 33 https://doi.org/10.1016/ S0959-6526(00)00028-7.

10. Muthusubramanian, L., Mitra, R.B., J Clean Prod, 2006, 14, 5, 536-538, https:// doi.org/10.1016/j.jclepro.2005.03.020.

(C) 2018 by the author(s). Published by INCDTP-ICPI, Bucharest, RO. This is an open access article distributed under the terms and conditions of the Creative Commons Attribution license (http://creativecommons. org/licenses/by/4.0/). 